\title{
DE
} DE GRUYTER OPEN

\section{STUDY ON THE INTERACTION BETWEEN CHINA AND JAPAN'S ECONOMY BASED ON FDI, IMPORT AND EXPORT TRADE}

\author{
WANGPING Yang \\ School of Economics and Finance, Xi'an Jiaotong University, China \\ XIAOLU Lu \\ School of Economics and Finance, Xi'an Jiaotong University, China
}

\begin{abstract}
:
In the context of global integration, one country's economic fluctuations will affect another country through a variety of ways, the global economic crisis in 2008 is the best proof. The economic ties between China and Japan are closely related. Japan was once the largest trading partner of China. It is very important to study the influence mechanism of economic fluctuations between China and Japan for the stable development of China's economy. This paper selects China's export to Japan(CEX). Japan's export to China(JEX), Japan's direct investment to China (FDI). Chinese gross domestic product (CGDP), Japan's gross domestic product (JGDP) five variables. We use impulse response and variance decomposition to analyze the interaction of Chinese and Japanese economy. Finally we come to the conclusion: China's economy affected by the impact of Japan's economic fluctuations bigger than Japan's economy affected by China; the contribution rate of imports from Japan is greater than the export to China's economy.
\end{abstract}

Key words: FDI, International trade, economic growth, VAR, impulse response

\section{Introduction}

In the current international environment, a country's economic fluctuations will affect the economy of another country in various ways, and the global economic crisis in 2008 is the best proof. Under open condition, we cannot close ourselves not to associated with other economies, what we should do is to study other economies how to influence us, then how to minimize the negative impact and does not affect the positive impact. This is the purpose of this paper. As Asia's two most important economies, the economic ties between China and Japan have been very close. Since 
1970s, the bilateral trade volume increased sharply, from about $1 \$$ billion to about 300 $\$$ billion, which turned hundreds of times; and the trade structure is more perfect, which is developed from vertical to horizontal division. Besides, Japan is also the most important funds sources of China. This close economic relationship makes the economies are vulnerable to another economy's fluctuations. In this paper, We use the Sino Japanese bilateral trade, Japan's direct investment to China to study how to influence each other between the two economies. Through the exploration of the impact mechanism, we can better avoid the impact, so that the national economy can be stable development.

\section{Literature review}

Research on international trade and economic growth: In eighteenth Century, Adam Smith (1974) put forward the thought that international division of labor to achieve mutual benefit. Based on this, Ricardo (1962) proposed comparative advantage theory, which emphasis on professional production to improve efficiency, so as to enhance the country's welfare. Ohlin-Heckcher theory proposed that countries participate in international division of labor according to their respective factor endowments, develop their own advantage industries, in order to achieve the optimal allocation of resources. The new trade theory take industrial organization and technology factors into consideration, proposed that the trade between developed countries belongs to intra industry trade, which is driven by specialization division, trade between developed countries and developing countries is inter industry trade, which is driven by endowment factor. Yao Feng and Shi Ningzhong (2003) use single direction causality measure and Wald statistical test theory to analysis the two economies' long-term relationship and causality for the past 20 years, theoretically affirmed the positive impact of international trade for Japan's economy. Zang Xuheng, Wang Liping and Zhang Jihai (2004) use simultaneous equations mode to study Sino Japanese trade's role to China's economic growth, finally draws the conclusion: trade between China and Japan not only promote China economic growth, but also promote the adjustment of China industrial structure. Wen Shaobo (2014) uses linear regression to study the impact of Sino Japanese trade on China's economic growth, and concluded that the scale expansion of Sino Japanese bilateral trade has a significant effect on China's economy.

Research on foreign direct investment and economic growth: different scholars have different views. Yang Wanping,Yuan Xiaoling (2009) studied American economic fluctuations' impact to China's economic growth by FDI, and finally come to the conclusion that American direct investment to China has not a positive role in promoting the economic growth of China. We should consider own conditions when we use foreign investment, and we cannot use foreign investment blindly. Liu Hong and Li Shusheng (2013) used VAR model to study the effect of FDI for Chinese economic growth and employment. Through the pulse analysis and variance decomposition, FDI 
has a positive impact for economic growth and employment, China should continue to create a favorable investment environment, and require not only quantity but also quality. Sun Yingming (2008) research on the relationship between FDI and GDP, and concluded that there is a positive correlation between the two, FDI has a very obvious effect to economic growth, China should continue to develop export-oriented economy.

Research on trade and economic fluctuation: Ning Guoyu and Ye Xiangsong (2012) establish autoregressive conditional heteroscedasticity model of Sino Japanese trade and GDP growth rate to study the relationship between Sino Japanese trade and China's macroeconomic fluctuation, and concluded that there is a positive correlation between the two, China's imports from Japan can promote the growth of China's economy whether it is long-term or short-term. Fu Jing (2007) uses the gray correlation analysis to analyze the relationship between Sino Japanese trade and China's economic development, finally find that Per capita GDP is the most affected by SinoJapanese trade, and it indicates that Sino Japanese trade has great significance on improving the living standards of Chinese. Pan Yanchen and Sun Jianming (2014) use the data of import and export volume growth rate and GDP growth rate from 1978 to 2012 to study, and find that there is a long-term equilibrium relationship between GDP fluctuation and the growth of international trade. The influence of GDP growth rate on international trade growth rate is greater than the influence of international trade growth rate on the GDP growth rate.

Research on foreign direct investment and economic fluctuation: Wang Ruidong (2013) use DSGE model to analyze the impact of FDI on China's macroeconomic fluctuations, and make a conclusion that FDI can change domestic asset price through inflation and improve the domestic financing constraints, then improve the financial situation of enterprises, so as to make the output scale of enterprise change, and then influence domestic economic development. Zhuang Zongming and Kongrui (2007) establish econometric models to study the impact of American direct investment on China's economic fluctuations, and make a conclusion that American direct investment for China has a negative impact on China economic growth, and this is mainly because American direct investment of Chinese mainly concentrated in the capital and technology intensive industry, which is not conducive to play Chinese labor advantage.

According to the literature, we find that there are some areas in need of improvement on Sino Japanese economic growth: (1) in the choice of variables, we find that most of the existing studies usually choice two variables of the FDI, import and export trade, economic growth to research, rarely put the three together to study the interaction between them; (2)on the processing method of FDI, and there is a controversial question to use stock or flow index. Actually, it is capital stock to play a stimulating role on economic growth. We learn from Yang Wanping's approach:.(3) in the method of empirical research, most of the existing literatures base on economic theory to study, but when we consider a lot of variables in the model, it is difficult to find an economic theory to explain. In this paper, we use the impulse response analysis and variance decomposition of VAR model to study the dynamic relationship 
between variables. Vector auto regression is a model that can be used as a function of all endogenous variables in the system, and it is a model for dealing with multiple relevant economic indicators. In 1980, Sims (C.A.SIMS) introduced the VAR model to economics, which promoted the wide application of dynamic analysis of economic system.

\section{Data sources and empirical methods}

\subsection{Data Sources}

The author used the data of China export to Japan(CEX), Japan export to China(JEX)、Japan direct investment to China (FDI)、Chinese gross domestic product (CGDP), Japan's gross domestic product (JGDP) between 1983 and 2014,and units are billion yuan.CEX and JEX are from the United Nations trade database. Japan's direct investment in China (FDI) and China's gross domestic product (CGDP) are from China Statistical Yearbook. Japan's gross domestic product (JGDP) are from the World Bank Database. In order to eliminate the influence of the different variances, the data is processed by logarithm.

On the processing method of FDI, and there is a controversial question to use stock or flow index. Actually, it is capital stock to play a stimulating role on economic growth. FDI from China Statistical Yearbook is shown in the flow, we need to calculate the stock. We refer capital calculation formula: FDI $_{t+1}=(1-\delta) \mathrm{FDI}_{t}+\frac{\mathrm{I}_{t+1}}{\mathrm{P}_{t+1}^{\mathrm{FDI}}}$ FDI FDI for the capital stock, I for new investment, $\mathrm{Pk}$ for the investor price index, T for the time, $\delta_{\text {for }}$ the depreciation rate. There is no authoritative data sources of initial investment and the rate of depreciation, and statistics about foreign investment in China began from 1983,so we have accumulated investment from 1979 to 1983 as the initial value, capital depreciation rate is $7.5 \%$, the assumption seems arbitrary, but it shows that the average life of capital goods is 13.3 years, in line with national recommendation service. The investment price index is replaced by the fixed asset investment price index.

\subsection{Empirical Method}

The traditional econometric method is based on the economic theory to describe the relationship between variables, however, it cannot explain the dynamic link between variables. Vector auto regressive (VAR) model is used to construct the model of each endogenous variable in the system as a function of the lag value of all endogenous variables. In 1980, Sims (C.A.SIMS) introduced the VAR model to the economics, which promoted the wide application of the dynamic analysis of the economic system.

The expression for the VAR model : 


$$
\left(\begin{array}{l}
y_{1 t} \\
y_{2 t} \\
y_{3 t} \\
\ldots \\
y_{k t}
\end{array}\right)=\Phi_{1}\left(\begin{array}{l}
y_{1 t-1} \\
y_{2 t-1} \\
y_{3 t-1} \\
\ldots \\
y_{k t-1}
\end{array}\right)+\ldots \ldots \Phi_{p}\left(\begin{array}{l}
y_{1 t-p} \\
y_{2 t-p} \\
y_{3 t-p} \\
\ldots . \\
y_{k t-p}
\end{array}\right)+\mathrm{H}\left(\begin{array}{c}
x_{1 t} \\
x_{2 t} \\
x_{3 t} \\
\ldots \\
x_{k t}
\end{array}\right)+\left(\begin{array}{l}
\varepsilon_{1 t} \\
\varepsilon_{2 t} \\
\varepsilon_{3 t} \\
\ldots . \\
\varepsilon_{k t}
\end{array}\right), t=1,2 \ldots \ldots T
$$

Among them, $y_{t}$ represents the $\mathrm{k}$ dimensional variable columns, $\mathrm{x}_{\mathrm{t}}$ represents $\mathrm{d}$ dimensional variables exogenous variables, $p$ represents the lag order, $t$ represents the number of samples.

This thesis studies the effect of Japan's economic fluctuations on the Chinese economy. We assume that the Japanese economy affect Chinese economy through the Sino Japanese trade, Japan's direct investment to China. We establish the VAR model which include China's gross domestic product (CGDP), Japan's gross domestic product (JGDP), China exports to Japan (CEX), Japan's exports to China (JEX), Japan investment in China (FDI) to study the mutual influence of Sino Japan economic relations. First, we examine the unit root test of the five variables to determine their stability, and then we take cointegration test to examine whether there is a long-term equilibrium relationship between them. This paper uses impulse response function and variance decomposition to analyze the dynamic relationship between variables. The main idea of impulse response function is that when an error term is changed, we could observes dynamic response of other variables to this shock. And the variance decomposition is used to analyze the contribution of each structure impact to the endogenous variable, which is used to reflect the importance of each impact on the change of endogenous variables.

\section{Empirical analysis}

\subsection{Unit Root Test And Cointegration Test}

Each time series is required to be stable in the analysis of impulse response function and variance decomposition. First, we carry out ADF test on five variables, and the test results are shown in the following table 1.We can see that we take unit root test of CGDP, JGDP, CEX, JEX, FDI after taking the logarithm ,the results show that they are not stable, then after the first order difference are stationary. Then the cointegration test is carried out on these variables, and the results are shown in table 2. We can see that there is a co integration relationship between these variables. 
Table 1: ADF Unit Root Test Results

\begin{tabular}{|l|l|l|l|l|}
\hline Variable & ADF test value & $5 \%$ critical value & $\begin{array}{l}\text { ADF } \\
\text { form }(\mathrm{C}, \mathrm{T}, \mathrm{K})\end{array}$ & test \\
\hline LNCGDP & -2.167219 & -3.562882 & $(\mathrm{C}, \mathrm{T}, 1)$ & stability \\
\hline LNJGDP & -1.452116 & -3.562882 & $(\mathrm{C}, \mathrm{T}, 1)$ & nonstationary \\
\hline LNCEX & -0.395881 & -3.562882 & $(\mathrm{C}, \mathrm{T}, 1)$ & nonstationary \\
\hline LNJEX & -1.731991 & -3.568379 & $(\mathrm{C}, \mathrm{T}, 1)$ & nonstationary \\
\hline LNFDI & -2.397100 & -3.562882 & $(\mathrm{C}, \mathrm{T}, 1)$ & nonstationary \\
\hline$\Delta$ LNCGDP & -4.457665 & -2.967767 & $(\mathrm{C}, 0,1)$ & stationary \\
\hline$\Delta$ LNJGDP & -3.877029 & -2.963972 & $(\mathrm{C}, 0,1)$ & stationary \\
\hline$\Delta$ LNCEX & -2.986059 & -1.952473 & $(0,0,1)$ & stationary \\
\hline$\Delta$ LNJEX & -3.732679 & -1.952473 & $(0,0,1)$ & stationary \\
\hline$\Delta$ LNFDI & -2.534493 & -1.952510 & $(0,0,1)$ & stationary \\
\hline
\end{tabular}

Note: $(\mathrm{C}, \mathrm{T}, \mathrm{K}), \mathrm{C}$ represents the constant term, $\mathrm{T}$ represents the trend term, and $\mathrm{K}$ represents the lag order, $\Delta$ represents first order difference.

\section{Table 2: Cointegration Test}

\begin{tabular}{lllll}
\hline Hypothesized & Eigenvalue & Trace & 0.05 & Prob. $^{* *}$ \\
No. of CE(s) & & Statistic & Critical Value & \\
& & & & \\
\hline None $^{*}$ & 0.874340 & 143.5163 & 69.81889 & 0.0000 \\
At most 1 & 0.712518 & 83.36523 & 47.85613 & 0.0000 \\
At most 2 & 0.610657 & 47.21394 & 29.79707 & 0.0002 \\
At most 3 & 0.481077 & 19.85844 & 15.49471 & 0.0103 \\
At most 4 & 0.028364 & 0.834442 & 3.841466 & 0.3610 \\
\hline
\end{tabular}

\subsection{Determine The Lag Order}

Because each of the endogenous variables in the VAR model can be expressed as the form of the lagged variables of all endogenous variables, we have to determine the endogenous variable lag order. We determined the VAR lag order is 2 by the following table 3 .We set up VAR (2) model of LNCGDP, LNJGDP, LNFDI, LNJEX, LNCEX to estimate the model. All units of the root of the model are less than 1 (as shown in Figure 1), so the VAR model meet the stability conditions, the estimated results for the VAR model: 


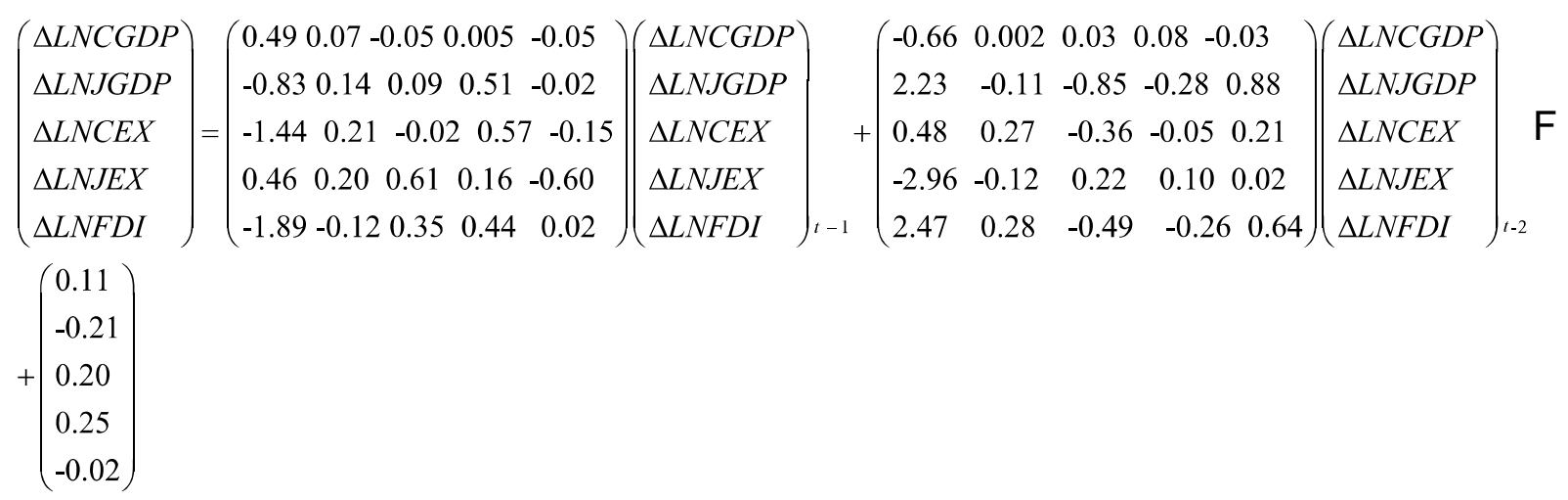

rom the above results, we can see that Chinese economic growth is influenced most by its own. Japan's economic growth will also promote the economic growth of Chinese, and Japan's export to China play a positive effect to the economic growth of China. China's exports to China play a negative role on Chinese economic growth. Japan's direct investment to China have a negative effect in the short term, which is mainly related with the lag effect of investment.

Table 3: Various Criteria To Select The VAR Lag Order

\begin{tabular}{|l|l|l|l|l|l|l|}
\hline Lag & LogL & LR & FPE & AIC & SC & HQ \\
\hline 0 & 147.9612 & NA & $2.53 \mathrm{e}-11$ & -10.21151 & $-9.973619^{*}$ & -10.13879 \\
\hline 1 & & & & & & \\
\hline 2 & 176.7518 & 45.24239 & $1.99 \mathrm{e}-11$ & -10.48227 & -9.054908 & -10.04591 \\
\hline 3 & 226.0055 & $59.80803^{*}$ & $4.26 \mathrm{e}-12^{*}$ & -12.21468 & -9.597845 & $-11.41468^{*}$ \\
& & & & & & \\
\hline
\end{tabular}

Note: * indicates the number of lags selected from each column

LR: the continuous correction of the LR test statistic (at the $5 \%$ level significantly)

FPE: the final prediction error

AIC:Akaike information criterion

$\mathrm{HQ}$ :Hannan-Quinn information criterion

SC:Schwarz information criterion 


\section{Inverse Roots of AR Characteristic Polynomial}

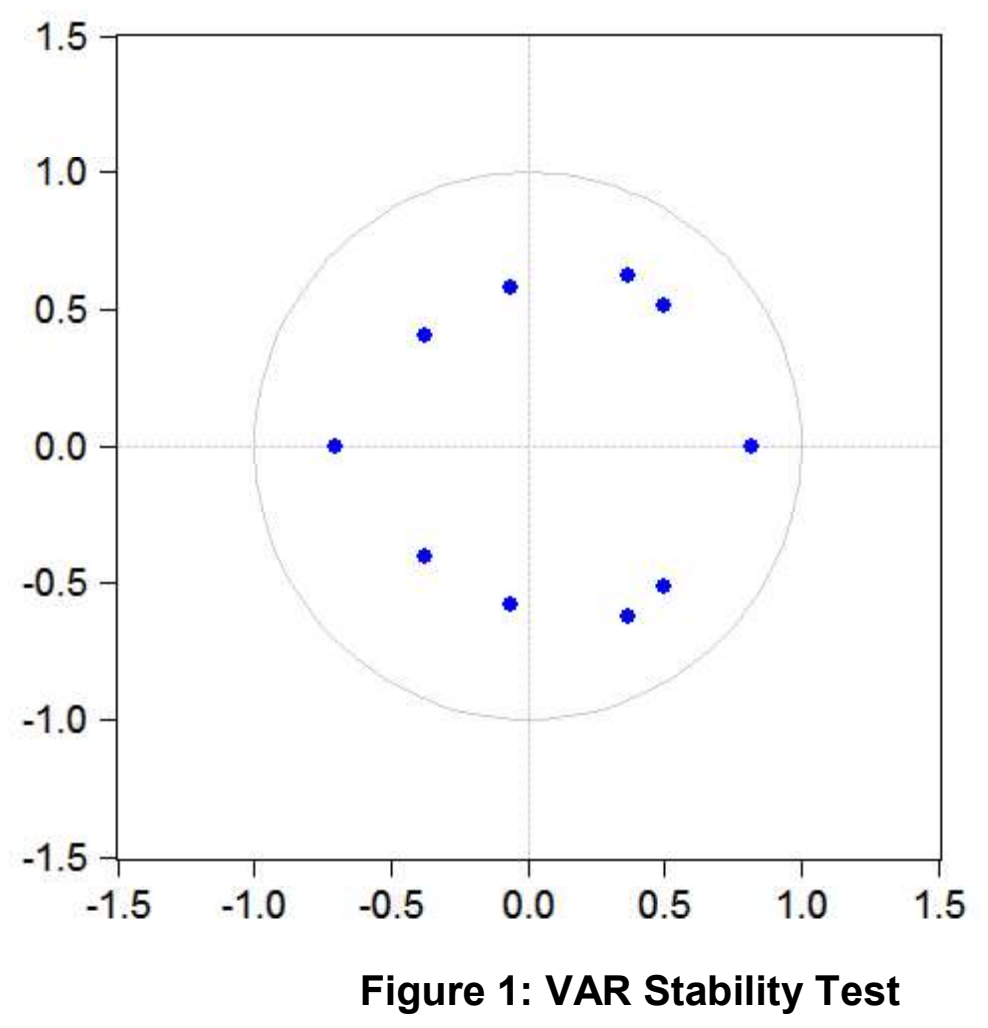

\subsection{Pulse Analysis}

When the covariance matrix is diagonal matrix, the result of Cholesky is consistent with that of the generalized impulse. When the covariance matrix is non diagonal matrix, the Cholesky quadrature pulse is equal to the generalized impulse only when the impact occurs in the first variable. The generalized impulse does not depend on the order of variables.When eviews calculate the generalized pulse of the first $\mathrm{J}$ variables, the first $\mathrm{J}$ variables is to be placed in the first order of Cholesky decomposition, and then calculate the impulse response of each variable.

The Chinese LNCGDP has an immediate response to a unit impact from its own, and in the first period to reach the maximum, then gradually decay, turning negative in the third period, then continue to decay to fourth to the negative maximum, after seventh to turn positive. The LNCGDP's reaction of the LNJGDP units impact is $N$ -shaped, and the first phase has a reaction and the reaction is positive, then increased gradually reached the maximum at the third phase ,after the third phase gradually decay, phase fourth was changed to negative, fifth to achieve the maximum negative, then gradually stabilized. The LNCGDP's reaction of the shock response from LNCEX is in the inverted $\mathrm{N}$ shape, and reach to maximum positive reaction at the first phase, then slowly decay, at the second phase reaction was negative maximum, from third phase began to turn forward, and reached the maximum positive reaction in the fourth period, then slowly decay, until stable. This shows that the impact of export on China's 
economy has a continuous process. The LNCGDP has a positive immediate reaction of LNJEX unit impact, and the reaction drop slightly after the second phase, at the third phase reached the maximum value, indicating that the effect of import on China's economy is lagging behind, after the third phase, the reaction gradually declined to be stabilize. The LNCGDP has a weak reaction of LNFDI unit impact in the spot, then gradually decay to negative maximum at the second phase, after third period becomes positive, fourth reached the positive maximum, then decline to be stabilized slowly.

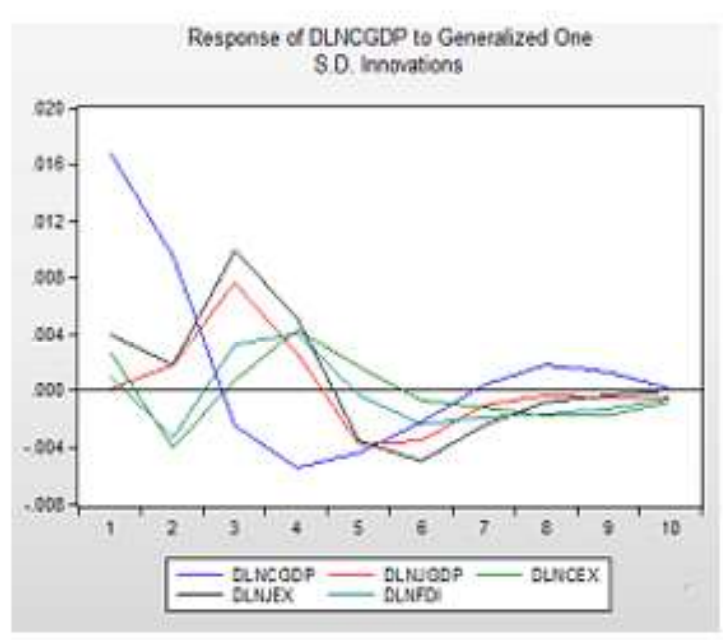

Figure 2: Response of DLNCGDP to

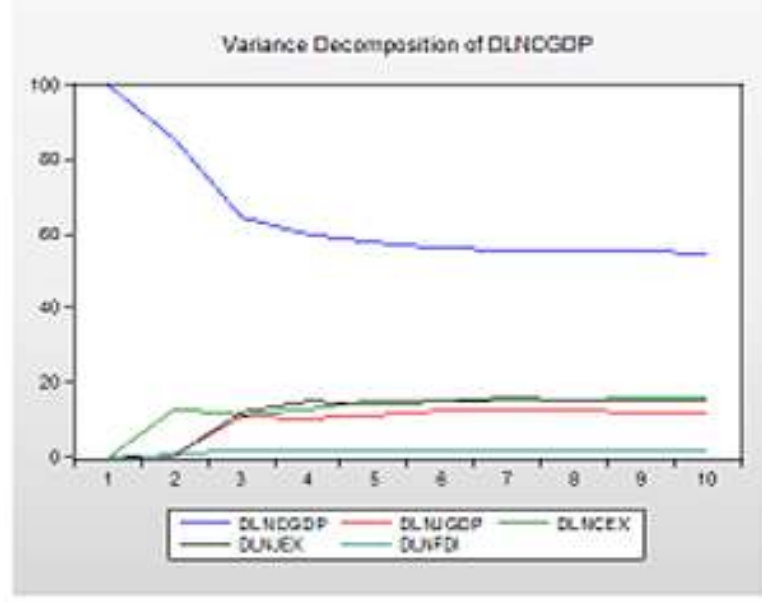

Figure 3: Variance Decomposition of DLNCGDP

Calculating cumulative response during the analysis period, the LNCGDP's reaction by itself, the LNJGDP, the LNJEX, the LNCEX, the LNFDI effect was positive, indicating that these factors have a stimulating effect on the Chinese economic growth, and greatest impact by its own, followed by the LNJGDP, impact of LNJEX is larger than the LNCEX , affected minimum by the LNFDI. And the stimulating effect on the economy of import is greater than that of export. This view is confirmed in a empirical study by Ding Zhengliang, Ji ChengJun which based on VAR model to study Chinese imports and exports, the real exchange rate and economic growth. Ding Zhengliang and Ji ChengJun think that import and export can promote the economic growth, but in the long term, imports' stimulating growth effect of economy is stronger than that of exports, which has a relationship with the trade structure. China's exports products mainly produced by cheap labor while China import from Japan mainly high-tech products, so Chinese must accelerate the transformation of industrial structure and improve the trade structure.

The LNJGDP has an immediate reaction to the impact from their own, and reach to the maximum value in the first period, and then fading slowly, reach to a negative impact at the third phrase, and reach to the negative maximum at the fourth phrase, to fifth becomes a positive impact, then gradually stabilized. The LNJGDP reaction is very weak of the LNCGDP unit impact at the first phase, then the reaction gradually increased, and achieve the maximum at third, after the third phase reaction gradually decreases and tends to be stable after fifth periods. The LNJGDP have a 
positive reaction from the LNJEX unit shocks at the first period immediately, then the reaction continues to increase, and reach to maximum at the second period, and the reaction gradual decline, and finally tends to be stable.

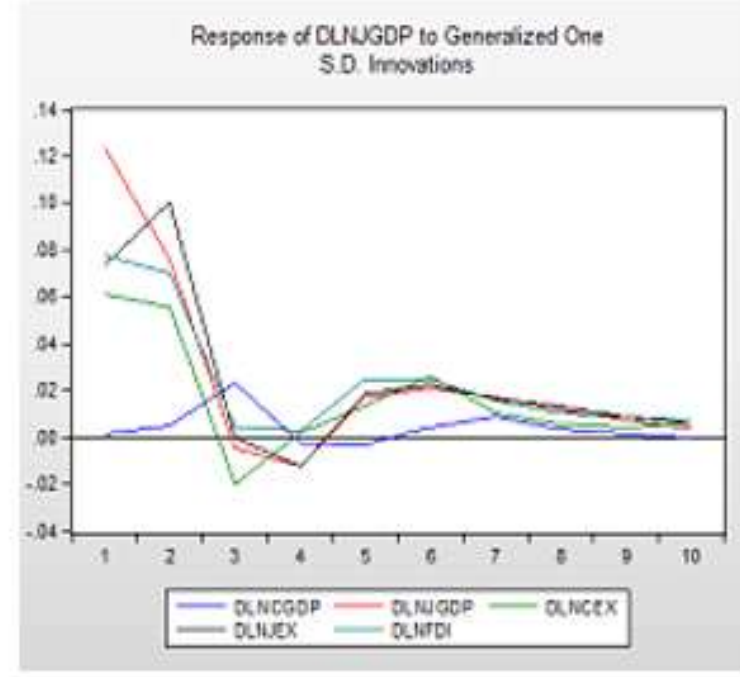

Figure 4: Response of DLNJGDP to

Generalized One S.D innovations

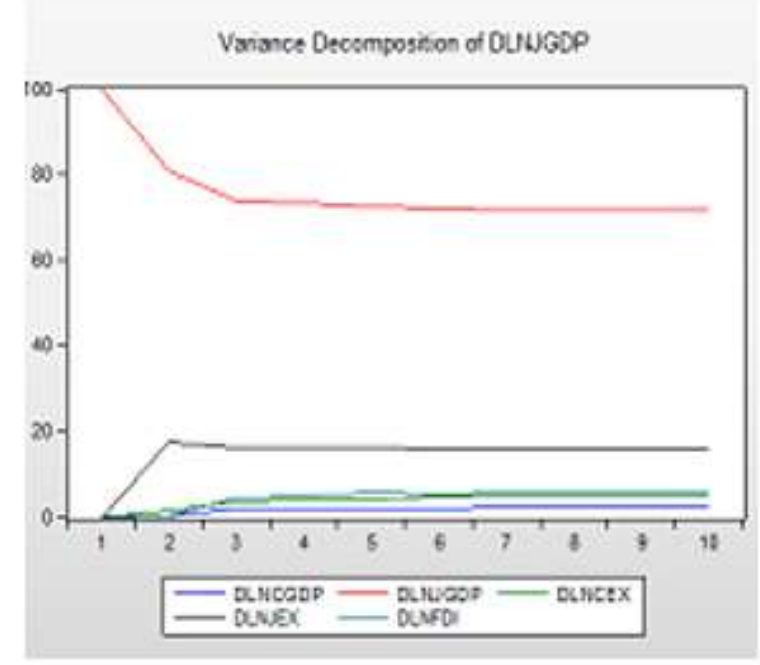

Figure 5: Variance Decomposition of DLNJGDP

This shows that Japan's exports to China has an obvious impact on the Japanese economy. The LNJGDP reaction reach the maximum of the LNCEX unit impact at the first period, then gradually decay until it is stabilized. The LNJGDP reaction reach the maximum from the LNFDI unit impact at the first period, then gradually decreases until it is stabilized. Calculating cumulative response during the analysis period, we find that LNJGDP's reaction is positive by its own, the LNCGDP, the LNJEX, the LNCEX and the LNFDI, and reactions affected by LNJEX, the LNCEX and the LNFDI are larger, affected by LNCGDP smaller, indicating that Japanese economy is influenced greatly by Sino Japanese trade, direct investment on China.

When China's exports to Japan are affected by its own, the first phase has a positive response and reach to the largest, and then followed by a gradual decline until it is stable. When China's exports to Japan are affected respectively by unit shock of the LNFDI, the LNJGDP, the LNCGDP, the reaction is roughly the same, that is, in the first period to reach the maximum, then gradually decay until it is stabilized. And the impact from LNJEX, the second period reach the maximum, there is a short lag period. Calculating cumulative response during the analysis period, we find that LNCEX affected by itself, the LNFDI, the LNJGDP, the LNJEX is bigger than that of LNCGDP. When Japan's exports to China are affected respectively by unit shock of itself and the LNCEX, the LNFDI, the LNJGDP, the LNCGDP, the reaction is roughly the same, that is, in the first period to reach the maximum, then gradually decay until it is stabilized. The difference is that the impact of LNCGDP on the impact duration is shorter than the rest. Calculating cumulative response during the analysis period, we find that $\triangle \mathrm{LNJEX}$ is affected by itself maximum, $\triangle \mathrm{LNCGDP}$ minimum. 


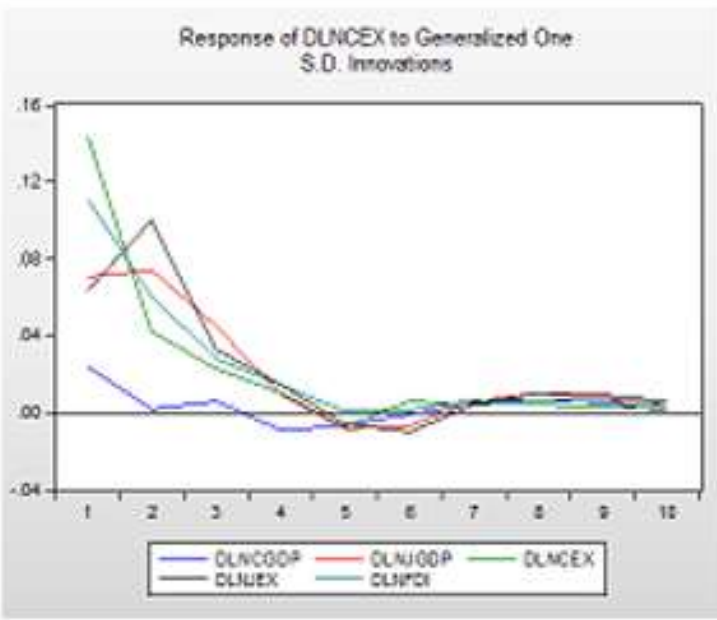

Figure 6: Response of DLNCEX to Generalized One S.D innovations

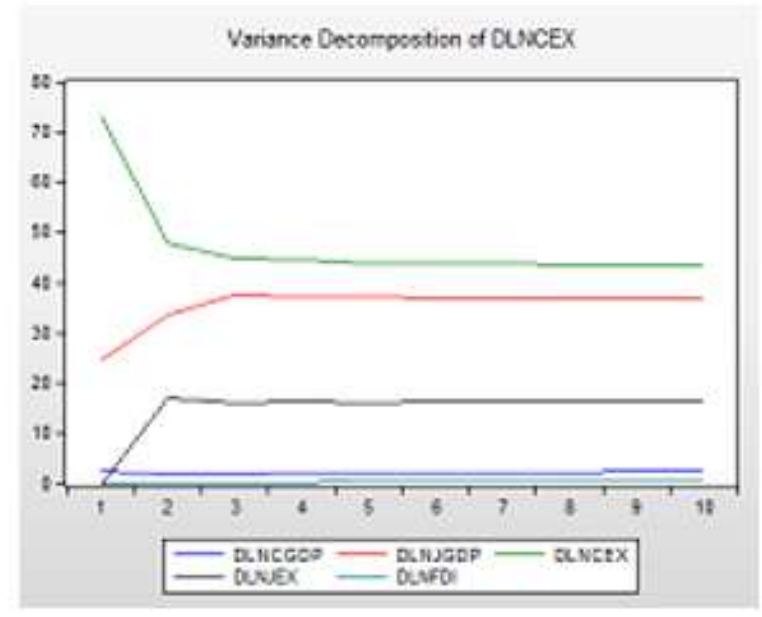

Figure 7: Variance Decomposition of DLNCEX

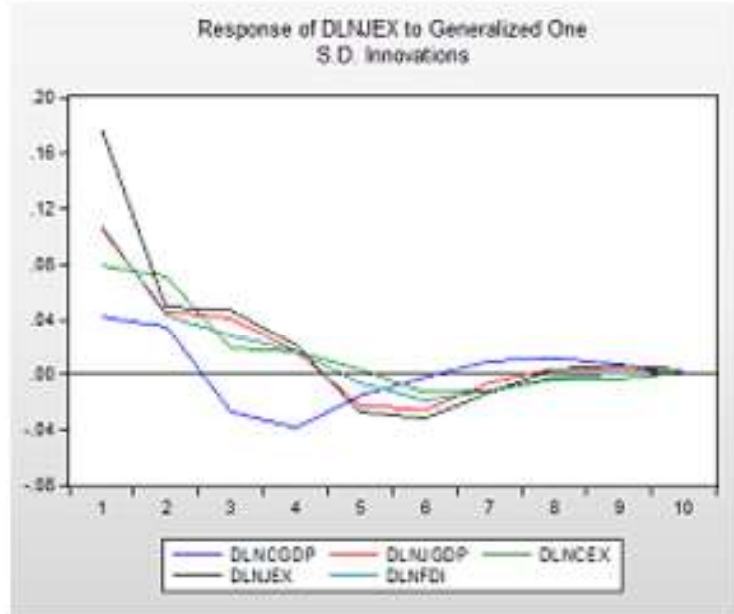

Figure 8: Response of DLNJEX to

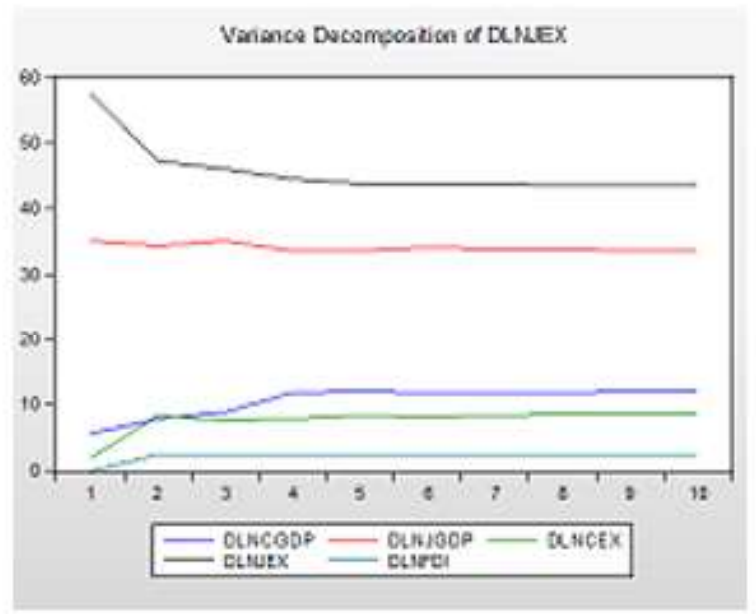

Figure 9: Variance Decomposition of DLNJEX

\section{Generalized One S.D innovations}

When Japan's direct investment to China are affected respectively by unit shock of itself and the LNCEX, the LNJEX, the LNJGDP, the LNCGDP, the reaction is roughly the same, that is, in the first period to reach the maximum, then gradually decay until it is stabilized. When LNFDI is affected by a unit shock of the LNJEX, there is an immediate reaction in the first phase, reach the maximum in the second period, and then gradually decay until it is stabilized. When LNFDI is affected by a unit shock of the $\triangle$ LNCGDP, there is an immediate reaction in the first phase, reach the negative maximum in the second period, and turn the positive maximum in the third period, then gradually decline to stabilize. 


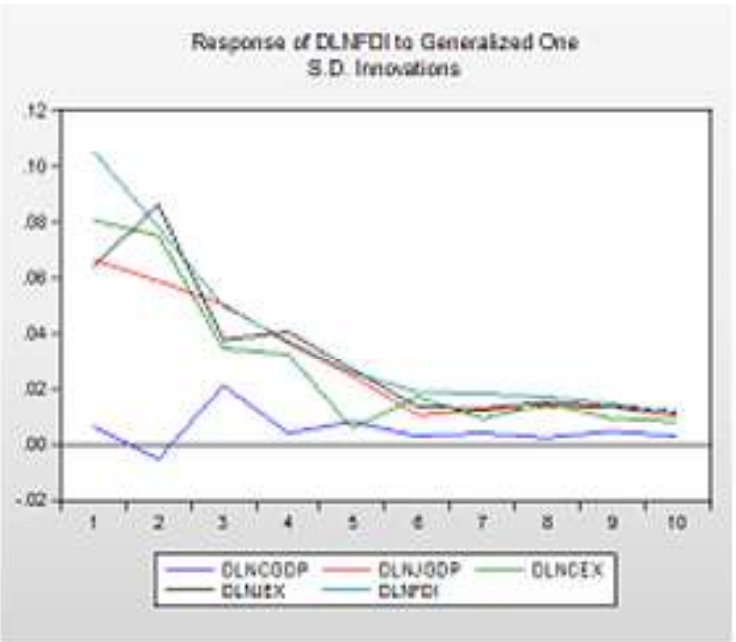

Figure 10: Response of DLNFDI to

\section{Generalized One S.D innovations}

\subsection{Variance Decomposition}

The impulse response function is mainly used to observe how the variables in the model react to the impact. The variance decomposition is used to illustrate the contribution of each structure impact to the endogenous variable, and further explain the importance of each impact. This paper selects 10 stage as the lag phase of variance decomposition. According to the established VAR (2) model ,We perform variance decomposition to the LNCGDP ,the LNJGDP, the LNFDI, the LNJEX, the LNCEX respectively. The specific variance decomposition is shown in Figure 3 , figure 5, Figure 7, figure 9, figure 11.

The variance decomposition of LNCGDP is shown in figure 3. The LNCGDP is affected by itself showing the declining trend, in the third period tends to be stable, finally the average level of interpretation reach $70 \%$; the extent of the LNCGDP explained by the LNJGDP increase gradually, and tends to be stable after the third period, and the average degree of influence reach to $18 \%$. The LNJEX, the LNCEX, the LNFDI has little effect on the LNCGDP, the average effect is about $5 \%$.

The LNJGDP variance decomposition is shown in figure 5. The LNJGDP variance decomposition results show that the explanation of LNFDI is constantly decreasing, to the second period tends to be stable, the average explained capacity of LNFDI is $45 \%$. The explanation by its own is rising, tends to be stable in the second period, average level is about $38 \%$. The explanation of the LNJEX also shows a rising trend, and tends to be stable in the second period, average level is about $15 \%$. The explanation by the LNCEX and the LNCGDP is very small , which can be ignored.

\section{Conclusion and suggestion}

In this paper, we use data from 1983 to 2014 to analyze the economic interaction between China and Japan. Through establishing the VAR (2) model of the 
LNCGDP, the LNJGDP, the LNJEX, the LNCEX and the LNFDI, we use impulse response and variance decomposition to study the Sino Japanese economic ,and draw the following conclusions:

(1) Chinese economy is affected by itself greatest, followed by the Japanese GDP, by the import and export trade and Japanese direct investment in China smaller. This shows that China is not export-oriented countries and not just rely on exports to stimulate economic growth, and China is the compound growth mode. On the other hand, it shows that China's economy is greatly influenced by Japan's economic fluctuations, and changes in Japan's GDP will cause a relatively large fluctuations in the China's economy .China's dependence on the Japanese economy is also very high, which is very detrimental to the stability of China's economy. China will try to change this situation.

(2) Japanese economy is affected by FDI greatest, followed by itself, and Japan's exports to China also have a great contribution to the Japanese economy. This is mainly because the main purpose of Japan's investment to China is to transfer the backward industries in China. It uses China's preferential policies, cheap land resources and cheap labor to obtain high profits. Japan's exports to China are high-tech products, and it is able to obtain excess profits. Japan's economy is less affected by China's GDP, which shows that Japan's dependence on the Chinese economy is relatively low.

As the two most important economies in Asia, the mutual influence between China and Japan is inevitable, but the Japanese economy is affected by China significantly less than China influence on Japan. The unequal relations make China are at the disadvantageous position in the economic, political and other fields. We need to strengthen Japan's dependence on China and reduce China's dependence on Japan, to make economic relationship between China and Japan in a relatively equal position.

So we put forward the following suggestions:

(1) We should improve the structure of export commodities, reduce the export of laborintensive products, increase the export of high value-added products. Exports can indeed boost economic growth, but if we blindly use the price advantage to exchange this benefit, China's economy cannot be able to get a stable and sustainable development. We should accelerate the R \& $D$ and innovation of technology and own our core competitiveness to achieve a real dominant position in the international market, so as to better rely on exports to stimulate domestic economic growth.

(2) We should increase the import of scarce resources and high-tech products. In recent years, the import's pulling effect of China's economic is more than exports, and the role of such effect last a long time. This is mainly because we import high technology goods industry, it can give China some advanced technology and stimulate Chinese technological progress and innovation, thus greatly stimulate economic growth of Chinese.

(3) We should improve domestic investment environment and enhance the absorption capacity of foreign investment. The above analysis shows that the impact of Japan's 
investment in China on China's economic growth is positive, but the reaction is very weak, which is mainly related to the domestic absorption capacity of foreign investment. China should improve the domestic financial market and enhance the efficiency of the use of funds. At the same time we should strengthen the domestic talent training to adapt the needs of these foreign capital and improve the absorption capacity of foreign capital.

(4) We should develop domestic demand economy and promote the reform of the supply side. Only stimulating domestic demand, can we achieve the long-term development of the economy. At present, the domestic demand insufficient is only superficial, supply and demand mismatch is the essence.It need start from the supply side, improve the domestic economic structure, reduce the supply of low-end products, expand high-end and effective supply, strengthen the supply side flexibility to demand, improve total factor productivity, to make supply better adapt to the demand. At the same time, we should actively create effective demand.

(5) We should properly handle the contradictions and frictions between China and Japan. There is contradictory on the issue of history and friction in the trade process between China and Japan. In view of the fact that China is still greatly affected by Japan's economic, when dealing with these problems, it should not hurt the development of China's national economy as a major premise, firmly grasp the basic principles of development is the last word. We should strengthen cooperation between China and Japan, actively develop Sino Japanese trade, and promote the healthy and stable development of China's economy.

\section{References}

Feng Yao, Shi Ning Zhong. (2003) Econometric analysis of the economic development of Japan and China Japan trade [J]. Management Science, 2003,6 (4): 55-62.

Guoyu Ning, Ye Xiangsong. (2012) Study on the influence of Sino Japanese trade on the China's macroeconomic fluctuations synchronization [J]. Macroeconomic Research, 2012, (12): (93-105).

Hong Liu, Li Shusheng. (2013) Impact of FDI on China's economic growth and employment study on the VAR model [J]. International Trade Issues, 2013, (4): 105-114.

Jiangyong Liu (2007). China and Japan: the change relationship between political and economy [M]. people's publishing house.

Jing Fu. (2007) Grey relational analysis of Sino Japanese trade and China's economic development [J]. Beijing Technology and Business University Journal, 2007 (7), 22 (4): 10-14.

Melvin James R., Chen Xue, Chen Linlin. (2005) Producer services trade: a method based on the Heckscher Ohlin model [J]. economic data, 2005 (4): 12-21.

Ricardo David (1962). Political economics and taxation principle [M]. translated by Wang Yanan. Beijing: the Commercial Press.

Ruidong Wang. (2013) FDI on the impact of macroeconomic fluctuations in China - based on the theory of financial accelerator DSGE model analysis [D]. Dalian: Dalian Technology University, 2013. 
Shaobo Wen. (2014) Study on the influence of Sino Japanese trade on China's economic growth [J]. Economic Forum, 2014 (4): 167-168.

Sims C.A., (1980) Macroeconomics and Reality, Econometrica,1980,48:1-48.

Smith Adam (1974). The study of the nation wealth [M]. Beijing: the Commercial Press,

Wanping Yang, Yuan Xiaoling. (2009) Study on the impact of American economic fluctuation on China's economic growth- Based on the generalized impulse response function method [J]. international trade issue, 2009, (8): 52-60.

Xuheng Zang, Wang Liping, Zhang Jihai. (2004) An empirical analysis on the effect of Sino Japanese trade on China's economic growth [J]. Journal of Shandong University, 2004, (1): 29-39.

Yanchen Pan, Sun Jianming. (2014) An Empirical Study on the relationship between international trade growth and economic growth in China [J]. Modern Economic Information, 2014 (9): 169-170.

Yingming Sun. (2008) An empirical study on the relationship between FDI and economic growth in China [J]. Heilongjiang Foreign Economic And Trade, 2008, (3): 28-30.

Zhengliang Ding. (2014) An Empirical Study of Chinese imports and exports, the real exchange rate and economic growth based on VAR model [J]. International Trade Issues, 2014, (12): 91-101.

Zongming Zhuang (2007). Sino US economic relevance research [M]. Economic Science Press. 